Bayero Journal of Pure and Applied Sciences, 5(2): 115 - 118

Received: November 2012

Accepted: December 2012

ISSN $2006-6996$

\title{
PROXIMATE COMPOSITION AND CONSUMER ACCEPTABILITY OF AFRICAN MUDFISH CLARIAS GARIEPINUS SMOKED WITH TWO ENERGY SOURCES
}

\author{
Yola, I. A. and Timothy, 0. \\ Department of Forestry, Fisheries and Wildlife, Faculty of Agriculture and Agric. Technology \\ Kano University of Science and Technology Wudil PMB 3244 Kano Nigeria
}

*Correspondence author: yolai2006@yahoo.co.uk

\section{ABSTRACT}

The aim of the study was to assess the organoleptic differences of Clarias gariepinus smoked with two different energy sources, Anogeissus leiocarpus and Tamarindus indica with the help of a hedonic scale and to determine possible proximate composition difference between the smoked products. Smoking of the fishes was carried out for 4 hours using traditional smoking kiln, the chemical analysis on the determination of moisture content, ash, crude protein, lipid and carbohydrate were carried out according to AOAC (1990) and hedonic scale was used to determine the organoleptic properties of the fish. The results of the sensory evaluation showed a strong organoleptic difference between the treatments in relation to the color, texture, taste and overall acceptability while more preference was observed for treatments smoked with Tamarindus indica which was characterized with more juiciness, more tenderness and a greater overall acceptability and for Anogeissus leiocarpus were poorer color and tenderness but better proximate quality. Fish smoked with Anogeissus leiocarpus recorded lower moisture, but higher dry matter, ash and crude protein content in comparison to fish smoked with Tamarindus indica. Organoleptic differences can be related to proximate analysis. It is therefore recommended that a knowledge of the energy source that can add value to smoked cultured fish be known so as to improve commercial value Key; Clarias gariepinus, smoking, Anogeissus leiocarpus, Tamarindus indica, proximate composition

\section{INTRODUCTION}

Fish constitutes a very important component of the diet for many people and often provides the much needed nutrient that is not provided in cereal based diets (Clucas and Sutchiffe, 1981). It was reported by Teutscher (1990); Saisithi (1994) that fish provides between $30 \%$ and $80 \%$ of the total animal protein intake of the coastal people of West Africa. Additionally, Olomu (1995); Kreuzer and Heen (1962); Waterman (1976) have also highlighted that fish is rich in protein with amino acid composition very well suited to human dietary requirements comparing favorably with egg, milk and meat in the nutritional value of its protein.

Fish is however susceptible to damage as soon as it harvested. Some factors responsible for this include the prevailing high temperatures in Nigeria and the facilities for processing, storing and distributing the fish caught are frequently inadequate or non-existent in most cases. There is therefore enormous waste through spoilage of both fresh and dried fish (UNIFEM 1988; FAO 1981; and Rawson 1996). Preservation of fish therefore generally slows down spoilage. Preservation methods are applied with an intention of making the fish safer and extend its shelf-life (Ghazala, 1994).

Acceptability of smoke-dried products however depends on the type of wood used (Tilgner, 1958; Maga, 1987: Regenstein, 1990). Fish is often smoked in some parts of northern Nigeria with Tamarindus indica and Anogeissus leiocarpus wood due to the abundance of the wood types in the region. Wood selection must be done with care as some wood like resinous types e.g. pine may impart unpleasant flavor and taste to the final product; while others like Euphobia species may be poisonous (UNIFEM, 1988).

Fish smoking is one of the most widely used traditional fish-processing methods. Various species of fish are smoked depending on the availability. Clarias gariepinus specie is among the most commonly cultured and smoked fish in Nigeria.

Fuel wood is the main source of energy for fish smoking. Although many wood types may be used as fuel for fish smoking among the many factors influencing the choice of wood, what is used depends on local availability. The fuel wood preferences of most fish smoker are also related to the physical characteristics of the wood and how they affect the smoked product (Nerquaye-Tetteh, 1985; Lartey et al.,, 1994). Different fuel woods may affect the quality of the smoked fish differently.

The organic constituents of the wood are reported to include cellulose, hemicellulose and lignin. When wood is burnt, the chemical compounds are broken down into many smaller compounds as a result of incomplete combustion (FAO, 1981; Storey,1982; Wheaton and Lawson, 1985). The characteristics of traditionally smoked products are to some extent dependent on the source of the smoke. A study on smoking fish with Eucalyptus wood in Zambia showed that the smoked product was golden brown and had a desirable texture as well as an appealing smoky aroma. There was no bitter taste when eaten and the product could sell well. (Mwambazi et al, 1995). Mensah (1998) also observed that some of the smoked fish from the Volta lake in Ghana which are black and unattractive are normally not due to charring but to the type of fuel wood used. 
Wood smoke is composed of vapor and particles that are easily taken up by moisture on the surface during smoking and they contribute to the characteristic smoke smell and color (Foster, et.al, 1961; Gilbert and Knowles, 1975; Hamm, 1977; Daun, 1979).

In addition to smoke imparting color and flavor-enhancing ingredients to the smoked product, wood smoke also has anti-oxidative and bactericidal properties (Barylko-Pikielna, 1977). Fish smoking has been practiced over the years in Nigeria and the fuel woods used are well documented. However the effect of different types of woods smoke on smoked fish is poorly documented. The aim of this study was to determine organoleptic differences in Clarias gariepinus smoked with two different energy sources, Anogeisus leiocarpus and Tamarindus indica with the help of a hedonic scale thus elaborating the differences in their proximate composition.

\section{MATERIALS AND METHODS Description of Study Area}

The study was conducted in the Department of Animal Science, Faculty of Agriculture, Bayero University Kano.

Kano lies between longitude $9^{\circ} 30^{\prime}$ and $12^{\circ} 30^{\prime \prime}$ North and latitude $8^{\circ} 42^{\prime}$ and $9^{\circ} 30^{\prime}$ East in the semi arid region of Northern Nigeria the state occupies a land area of $20,400 \mathrm{~km}^{2}$ with a population of over ten million people (Census, 2006). Hausa - Fulani are the major ethnic group in the area and Islam is the dominant religion. The climate of Kano is hot during dry season and cold during harmattan. The ambient temperature ranges from $16.6^{\circ} \mathrm{C}$ to $42.8^{\circ} \mathrm{C}$ in the months of January to June and $23.9^{\circ} \mathrm{C}$ to $26.7^{\circ} \mathrm{C}$ in July to December (Anonymous, 2010). An average monthly precipitation of 0 to $30 \mathrm{~mm}$ was recorded in January to June and 780 to $1320 \mathrm{~mm}$ in July to December (KNARDA, 2001). Trading is the main occupation of the people living in the metropolis of Kano while in other areas farming is the main occupation.

\section{Collection of Fish Samples}

Samples of Clarias gariepinus were obtained fresh and slaughtered on the 16th of November, 2011, from the Kano University of Science Technology, Wudil Pond. taken in ice chest to the traditional kiln smokers located at Galadima road, Kano state, where the fish samples were smoked using with two different energy sources, Tamarindus indica and Anogeissus leiocarpus as a source of heat after which the smoked samples

\section{RESULTS AND DISCUSSION}

The results obtained from the experiments are presented below:

Table 1: Proximate composition of Clarias gariepinus smoked under two energy sources

\begin{tabular}{lllll}
\hline Parameter & T. indica & A. leiocarpus & Air dried & LSD \\
\hline Ash & $7.54^{\mathrm{a}}$ & $8.67^{\mathrm{b}}$ & $8.24^{\mathrm{c}}$ & 0.44 \\
Moisture & $7.33^{\mathrm{b}}$ & $6.87^{\mathrm{a}}$ & $8.3^{\mathrm{c}}$ & 0.52 \\
Dry Matter & $92.67^{\mathrm{a}}$ & $93.12^{\mathrm{b}}$ & $91.7^{\mathrm{a}}$ & 0.42 \\
Crude Protein & $27.34^{\mathrm{a}}$ & $29.42^{\mathrm{b}}$ & $32.25^{\mathrm{c}}$ & 0.68 \\
Lipid & $6.26^{\mathrm{b}}$ & $5.41^{\mathrm{a}}$ & $7.02^{\mathrm{c}}$ & 0.89 \\
\hline
\end{tabular}

*Means in the same rows with the same superscript are not significantly different.

Table 2: Sensory Evaluation of Clarias gariepinus smoked under two energy sources were taken to the Animal Science Laboratory of Bayero University, Kano State for proximate analysis.

\section{Smoking process}

The fish samples were gutted and washed thoroughly with clean water and the samples were then kept on racks and put on the traditional oven. Smoking of the fishes was carried out for $4 \mathrm{~h}$. The maximum smoke was produced by the burning of Tamarindus indica and Anogeissus leiocarpus wood, thus two different ovens were used respectively to smoke the fish samples and some were air dried as control treatment. After smoking, the products were packed in transparent polythene bags and sealed to reduce microbial infestation.

\section{Preparation of Fish Samples}

Prior to analysis, the smoked fishes were washed, dressed and chopped into pieces. The smoked samples were blended and homogenized using mortar and pestle. They were packed in different bottles and labeled accordingly.

\section{Proximate Analysis of Fish Samples}

The chemical analysis on the determination of moisture content, ash, crude protein, lipid and carbohydrate were carried out using guidelines of Association of Official Analytical Chemists AOAC, (1990).

\section{Organoleptic Assessment}

Organoleptic evaluation of the smoked Clarias gariepinus was performed with the aid of seven (7) panelists and were analyzed for tenderness, flavor, color, juiciness, texture and overall acceptability on a 1-9 hedonic scale as follows (Ihekoronye and Ngoddy, 1985):

1. Like extremely

2. Like very much

3. Like moderately

4. Like slightly

6. Dislike slightly

7. Dislike moderately

8. Dislike very much

9. Dislike extremely

\section{Statistical Analysis}

All data were subjected to analysis of variance (ANOVA) and Duncan's multiple range tests for mean separation using SAS computer software. temperature in the smoking chamber was $100^{\circ} \mathrm{C}$. The

5. Neither like nor dislike 


\begin{tabular}{llll}
\hline Parameter & T. indica & A. leiocarpus & Air dried \\
\hline Tenderness & $1.85^{\mathrm{a}}$ & $3.42^{\mathrm{ab}}$ & $3.28^{\mathrm{b}}$ \\
Flavor & $2.14^{\mathrm{a}}$ & $3.14^{\mathrm{b}}$ & $3.28^{\mathrm{c}}$ \\
Color & $1.28^{\mathrm{a}}$ & $3.28^{\mathrm{c}}$ & $4.14^{\mathrm{b}}$ \\
Juiciness & $2.42^{\mathrm{b}}$ & $2.85^{\mathrm{b}}$ & $3.85^{\mathrm{a}}$ \\
Texture & $2.85^{\mathrm{a}}$ & $3.0^{\mathrm{c}}$ & $3.42^{\mathrm{b}}$ \\
Overall Acceptability & $1.71^{\mathrm{a}}$ & $2.57^{\mathrm{c}}$ & $2.91^{\mathrm{b}}$ \\
\hline
\end{tabular}

*Means in the same rows with the same superscript are not significantly different.

The study showed that Clarias gariepinus fish smoked with Tamarindus wood lost moisture more than when smoked with Anogeissus wood and air drying. Ash content of smoked fish showed similar pattern with moisture content giving a significant difference $(P<0.05)$ between the treatments as indicated in Table 1 . The crude protein content and dry matter content showed significant $(P<0.05)$ difference between fish smoked under different energy sources. Nevertheless there were significant $(P<0.05)$ changes in dry matter content as indicated in Table 1

The present study indicates that there was significant difference $(P<0.05)$ in color, texture, taste, and overall acceptability and slight difference in the juiciness of Clarias gariepinus smoked with Anogeissus leiocarpus, most of the assessors were not able to differentiate between them as indicated in Table 2 . While, Clarias gariepinus smoked with Tamarindus indica was found to have distinct tenderness, flavor, color, juiciness and having higher overall acceptability than the other two treatments. The present study agrees with the results of Mensah (1998) on sensory properties being preferred based on wood type used in smoking.

Concerning the flavor, it indicates that the higher fat content in cultured fish affect taste giving

\section{REFERENCES}

Anonymous (2010) Kano State. http://en.wikipedia.org/wiki/kano_state

AOAC. (1990). Official Methods of Analysis. (15 (edn.), K. Holdrick, Editor. Association of Official and Analytical Chemists, Virginia, U.S.A, Pp. 125-291.

Barylko - Pikielna, N (1977) contribution of smoke compounds to sensory, bacteriastatic and anti-oxidative effects on smoked foods. Pure Appl. Chem. 49, 1667 - 1671.

Census (2006). National population Commission, Abuja, Nigeria

Clucas I.J. and Sutcliffe P.J. (1981). An Introduction to Fish Handling and Processing. Tropical Products Institute. London, 86pp.

Daun, H. (1979) Interaction of wood smoke components and foods. Food Technology. $33(5), 66,68,70-71,83$.

FAO (1981). The prevention of losses in cured fish. FAO Fish. Tech. Pap; (219) 87p. Farmed sea them the characterization of more juicy and a white flesh. In a study on Salmon, Rawson (1998) had shown a very strong correlation of sensory fatness and juiciness to the fillet fat content. Although fats have been proposed to modify tenderness, bite, lubrication, elasticity and juiciness, the precise mechanism of action of lipids is very difficult to define (Maga, 1987). It was found that Anogeissus leiocarpus and Tamarindus indica woods used for the taste panel in the present study differed significantly in their color, texture, and flavor and overall acceptability of the fish samples.

\section{CONCLUSION AND RECOMMENDATION}

This research was able to provide evidence of strong organoleptic differences between the different treatments upon sensory evaluation. This indicates that Clarias gariepinus if smoked with Tamarindus wood has high acceptability to consumers in term of eating quality but Anogeissus wood gave less moisture and better retention of chemical constituent of the fish. It is recommended to use Tamarindus wood for short storage period and Anogeissus wood for long term storage.

bass (Dicentrarchus labrax) and gilthead sea bream

Foster, W. W. Simpson, T. H and Campbell. D. (1961) studies on the smoking process of foods. 2. The role of smoke particles. I Sci. Food Agric. 12. 635 - 644

Ghazala S. (1994). New packaging technology for seafood preservation, shelf-life extension and pathogen control. In Fisheries Processing Biotechnological Applications (Ed. Am Marthin). Chapman and Hall, London pp. 83-110.

Gilbert, J. and Knowles, M.F (1975) The Chemistry of smoked foods: A review. J. Food Technology. 10 (3), 245.

Hamm, R (1977) Analysis of smoked and smoked foods. Pure Appl. Chem. 49, 1655 - 1666.

Ihekoronye, A. I and Ngoddy P. O. (1985). Integrated Food Science and Technology for the Tropics. Macmillan Publishers London. Pp. 75- 77. 
KNARDA (2001) Meteorological station report temperature record book, Land management unit No. 11. pp $1-3$

Kreuzer, R. and Heen, E. (1962). Fish Nutrition. London Fishing News Book Ltd. 445p.

Lartey, A., Asiedu, M. and Okeke, E.C (1994) Assessing the effects of different smoking ovens and fuel wood types on fish nutritional quality. Progress report submitted to: Ghana/Netherlands Artisanal fish processing and Applied Research project in Africa. University of Ghana, Legon.

Maga, J.A. (1987). The flavour chemistry of wood smoke. Food Rev. int. 3:12, 139-183.

Mensah, E.M (1998). Fish processing method on Volta lake and related innovations. Proceedings of $4^{\text {th }}$ FAO Export consultation on fish technology in Africa. Food and Agriculture Organization, Rome Italy.

Mwanbazi, V.C.D, Aarnink, B.H.M, lubilo, R, Mwaba, E.D, Mwiya, M. and Ngula, E. (1995). Postharvest programme Mweru-Luapula; A report on the demonstration and trial programme on the mud chorkor kiln and use of Eucalyptus wood for smoking fish. Department of fisheries, Nchelenge, Luapula Province, Zambia.

Nerquaye - Tetteh, G (1985). A case study on utilization of wood in fish smoking industry. FAO Resource paper, food and Agriculture Organization. Fisheries division, Rome, Italy.

Olomu, J.M. (1995). Monogastric Animal Nutrition Jachem Publications, Benin City. Pp. 165200.
Rawson G .C (1996). A Short Guide to Fish Preservation. Rome U.S Food and Agriculture Organisation. 42-58.

Regenstein, J.M. (1990). Smoke itself. In: Introduction to fish Technology. Van Nostrand Runhold, N.Y. pp. 127-131.

Saisithi, P. (1994). Traditional fermented fish source production. In Fisheries Processing Biotechnological Applications. Marthin A.M. (ed) Chapman and Hall, London p. 201-217.

Storey, R.M (1982). Smoking. In Fish Handling and Processing (ed. A. Aitkin, I.M Mackie, J.H. Merrit and M.L Windsor). Ministry of Agriculture, Fisheries and food. Tony Research station, Edinburgh. Her Majesty's stationary office. Pp. $98-114$

Teutscher, F. (1990): The Present and Potential role of small Inland Species on food supply and income generation in Eastern Southern Africa. In: CIFA Tech. Pap. No. 19, Rome, FAO 1992, pp. 18-21.

Tilgner, D.J. (1958). Analaysis and use of smoke from various kinds of wood. Fleschirtschaft 10: 751. to the Salmoned Trout. Brazilian Arch. Biol. Technol. 49(1): 57-62

UNIFEM (1988). Fish Processing. The United Nations Development Fund for Women (UNIFEM) for Food Cycle Technology Source Book. Project GLO/85/W02. 9/pp.

Waterman, A. (1976). The Production of Dried Fish. FAO Fish. Tech. Paper (160):115-120.

Wheaton, F.W and Lawson, T.B (1985). Processing Aquatic Food Products. John Wiley and Sons Inc. pp. $79-105$ and pp. 273 - 327. 